Article

\title{
Posthuman Ethics, Violence, Creaturely Suffering and the (Other) Animal: Schnurre's Postwar Animal Stories
}

\author{
Belinda Kleinhans \\ College of Arts and Sciences, Classical \& Modern Languages \& Literatures, Texas Tech University, Box 42071,
} Lubbock, TX 79409, USA; belinda.kleinhans@ttu.edu; Tel.: +1-806-834-2702; Fax: +1-806-742-3306

Academic Editor: Myra Mendible

Received: 1 June 2016; Accepted: 17 August 2016; Published: 19 August 2016

\begin{abstract}
The othering of whole groups of people in a biopolitical discourse during the Third Reich has caused many to re-assess ethics that is based on specific categories. Adorno and Horkheimer reckoned with both Enlightenment as well as classical "humanist" discourses to question whether they imply structures that lead to fascism. In the wake of these arguments, classical humanist (or sometimes also called anthropocentric) ethics have also been criticized by philosophers such as Agamben, Derrida, and Wolfe. It is thus time to work on posthuman(ist) ethics that avoids the traps of a narrow human ethics and that is inclusive rather than exclusive. The short stories by postwar German author Wolfdietrich Schnurre, written in the wake of the Holocaust, reckon with a purely human-centered worldview and draw a bleak picture of an anthropocentrically structured and valued world. Under the surface that portrays a speciesist world, Schnurre employs a network of sub-discourses to "cave out" carno-phallogocentric discourses and point towards a different, post-human ethics. This paper examines how anthropocentric discourses of power lead to inhumane violence and how a different approach to the Other, based on empathy and shared vulnerability, might just move us beyond it.
\end{abstract}

Keywords: animal studies; posthuman ethics; postwar German Literature; violence

\section{Introduction}

When considering posthumanist ethics, ${ }_{1}^{1}$ sooner or later one ends up at the question of the animal: The broad category of "animal" as the ultimate Other, the non-human, serves easily as a "testing ground" upon which to evaluate any ethics centered on encountering the "Other". In over 2000 years of Western philosophy, the animal was always the Other against which humans were able to recognize themselves - as the superior being, as the being with language, rationality and thought, and as something that we know today as the Cartesian subject. The philosopher Giorgio Agamben diagnoses the history of both science and philosophy in his book The Open [1] as part of what he calls the "anthropological machine" through which the human is created with and against the animal. Traditionally, the animal was the Other that was to be excluded from the human sphere-and also from the sphere of law and ethics.

I thus turn to the question of the animal to understand the challenges we face when attempting to achieve an ethical encounter with the Other, since the binary of human vs. animal is one of the harshest

\footnotetext{
1 "Posthuman" or "posthumanist" in this context is a term borrowed from Cary Wolfe. It does not refer to concepts that come after the human, surpass humankind in one way or another, or overthrow humanism and its concepts altogether. Rather, it is a way of thinking that tackles some of the unquestioned assumptions in humanism (such as the implied anthropocentrism and the speciesism connected to it) and tries to come to a more holistic conception that is not based on our mutual belonging to the same species or category, but is based on a recognition of our shared responsibility to one another.
} 
when it comes to ethical thinking. The binary discourse of species that puts man in the center and at the top has received a lot of criticism, most prominently through Peter Singer's term "speciesism" [2], which describes the hierarchy between man and animal that subjects the animal and denies it any rights, based on its lack of rational thought. At the core of speciesism lies the ethical acceptability of the systematic "noncriminal putting to death" of animals based solely on their species and thus their position outside of the law-something Cary Wolfe and Jacques Derrida have both criticized and problematized (see $[3,4])$. Because of this implicit problem of hierarchy that is often inherent in humanism (see [5]) and the value that is placed on life based on its exclusion or inclusion in a certain category, today we face the need for posthuman ethics: "because the discourse of speciesism...can be used to mark any social Other, we need to understand that the ethical and philosophical urgency of confronting the institution of speciesism and crafting a posthumanist theory of the subject has nothing to do with whether you like animals. We all, human and nonhuman alike, have a stake in the discourse and institution of speciesism" ([4], p. 7; emphasis in original). Developing a posthuman ethics that challenges speciesism and includes all Others_-also animals_-is a necessary step toward dismantling racism and the violence inherent in it.

Combining posthumanist and deconstructionist theory with literary studies in this article allows me to trace the workings of speciesist and exclusive discourses based on categories (such as "human" and "animal") in order to show how they are motivated by violence. The category of the animal, metaphorically, allegorically, and also literally, has frequently been used and abused to justify violence and subjection, as Wolfe also points out: "Violence against human others [...] has often operated by means of a double movement that animalizes them for the purpose of domination, oppression, or even genocide-a manoeuvre [sic!] that is effective because we take for granted the prior assumption that violence against the animal is ethically permissible" ([6], p. 567). It is this ethical acceptability and its implications within the categories of "man" and "animal" that are the focus of this essay, since they flow from an anthropocentric worldview that enables a biopolitics which can justify putting an Other to death without any ethical responsibilities. ${ }^{2}$ This is something that applies to relations within the species boundary as well, as the philosopher Roberto Esposito [7] has pointed out. The Thanatopolitics that drove the Holocaust used animalizing metaphors and the very hierarchy implied in the human-animal binary, marking Jews as rats and other pests, in order to remove them from the realm of ethical consideration:

The Jews didn't resemble parasites; they didn't behave as bacteria-they were bacteria who were to be treated as such. In this sense, Nazi politics wasn't even a proper biopolitics, but more literally zoopolitics, one expressly directed to human animals. Consequently, the correct term for their massacre-anything but the sacred 'holocaust' — is "extermination": exactly the term used for insects, rats, and lice. Soziale Desinfektion it was called ([7], p. 117).

The importance of the implications of the anthropocentric worldview and the human-animalbinary become apparent if one looks at the use of animal metaphors during the early 20th century and especially during the Third Reich. In this context, it is understood that whoever falls under the category of animal has, by definition, no rights and no ethical claims, and the human-animal binary is thus crucial in establishing and exerting power. The two short stories by post-WWII German author Wolfdietrich Schnurre ${ }^{3}$ I will analyze, written in 1952 and 1958 as a response to Third Reich

2 While the power hierarchies and violence related to man and animal have been discussed in gendered terms, most prominently by Carol Adam's The Sexual Politics of Meat. A Feminist-Vegetarian Critical Theory, I will focus less on the aspect of gender, since I am aiming at posthuman ethics that would apply to men and women equally. Aligning it too much with gendered categories (instead of the workings of certain subject positions) could make it appear to mean that women are excluded from such an ethics, or "automatically" act ethically, which is not the case.

3 Wolfdietrich Schnurre was born in 1920 in Germany and also lived there throughout the duration of the Third Reich. He observed first-hand the function of discourses of power and violence that use the idea of dehumanization and animalization as well as the connected structures of inclusion and exclusion during the Third Reich. 
society, give a detailed account of the workings of a world based on speciesism. On the surface, these short stories reproduce the narrative violence of narrow anthropocentric ethics that excludes vast categories of Others and chronicle how these categories are used to exclude and violate. They can help to illuminate how and why a speciesist way of viewing the world is infused with violence. A detailed understanding of how the process of othering works and what role violence plays in it is necessary to develop ethics that successfully challenge speciesist thinking.

Furthermore, the two short stories do not stop at a portrayal of speciesist thinking and the violence that flows from it. Rather, their implicit and explicit ethical statement is an acknowledgement of interconnectedness and precarious life that is similar to Judith Butler's conception of an ethics of cohabitation (see [8]) and reminiscent of Emmanuel Levinas' ethical concept of encountering the Other. However, the predominant place of violence and the attempt to establish positions of power in both short stories underscore the importance of an understanding of violence and power hierarchies for the emergence of posthuman ethics. Through the focus on the animal's face and the intertwining of human and animal fates, Schnurre's short stories manage to show how violence directed at the Other ultimately destroys the perpetrator of violence, too, by destroying his humanity and individuality. On this second, deeper level, Schnurre poetically subverts the first narrative level of a speciesist worldview and dares readers to challenge their assumptions about who deserves ethical consideration. The violence of othering encompasses both perpetrator and victim and makes clear that a different approach to the Other is needed in order to preserve both sides. While animals are at the core of his representations, Schnurre's short stories are neither only about animals, nor only about human guilt and suffering, as they are usually perceived. Rather, they go further by showing the way to develop literary posthuman ethics that are not based on categorizations, but instead on mutual recognition and the value of life and suffering that is shared across species boundaries.

Discourses of violence between humans and animals matter because they have shaped and still do shape structures of violence against any Other, whether human or animal. Analyzing literary animals in this context can help us gain two important insights: First, they can help us identify how narrative violence shapes individual as well as collective actions; and second, they can get us thinking about how we, through the recognition of these violent structures, can develop different narrative structures of belonging and relating, which in turn can contribute to posthuman ethics. Posthuman ethics, then, is based on the insight of the interconnectedness of actions, lives, and suffering, which I explore in this paper.

\section{Violence and the Other}

Schnurre's two short stories "Das Manöver" (The Maneuver, 1952) and "Die Tat" (The Act/Deed, 1958) are central to the analysis of violence created in a purely anthropocentric and speciesist worldview and to an implicit emergence of posthuman ethics. Wolfdietrich Schnurre's narrations and animal texts make explicit references to geographical places and historical times, so that they directly reflect the postwar situation in Germany. The context of the postwar situation is important, since the Third Reich excelled at using animalizing discourses, or as Esposito put it, zoopolitics, in order to not only discriminate against Others, but exterminate them (see [7], p. 117). In Schnurre's texts, we find violence often directed at the animal instead of human Others. Through their focus on violence in connection with non-human life, many of his texts explicitly negotiate the anthropocentric-speciesist worldview of the early 20th century by creating a confrontation between human and animal.

"Das Manöver", a short story that is usually interpreted as a comment on the rearmament of Germany ${ }^{4}$, depicts a military exercise in which a general wants to show a group of high-ranking

4 The rearmament of Germany after the capitulation at the end of World War II falls into the 1950s and was met by the public as well as by politicians with a lot of criticism. Schnurre was among those intellectuals who publicly spoke out against it. His short story "Das Manöver", circling around a military exercise and written in the early 50s, was often read and understood as a comment on the rearmament, while the aspect of animal life in it were largely neglected in interpretations. 
military officers his newly trained soldiers in action. A large flock of sheep appears during the exercise and disrupts the maneuver. All the soldiers' efforts to chase the animals away fail. In an attempt to restore order, the embarrassed general tries to take matters into his own hands by driving his jeep into the flock and randomly shooting into the mass of animals. After the jeep is overturned by the animals, a showdown follows in which the general has to face a huge ram who was wounded in the shooting. In this confrontation, the general dies at the ram's horns. The story ends with the army corps being embarrassed and having to abort their maneuver while wild animals return to their habitat, which had been disturbed by the military exercise.

In "Die Tat", a black cat haunts four narrative levels of a plot that describes Germany prior to WWII, during the war, and afterwards. On the chronologically earliest narrative level, two children, Erwin, eleven years old and Zabel, eight years old, discover a black cat in an upside-down bucket. They hit the cat with clubs and fists until her body is completely broken, and the younger child notices the bodies of several kittens - a sign that the cat was pregnant before it was mutilated and killed by the boys. Zabel, the younger child, interrupts Erwin at the sight of the dead kittens and attacks him instead, and when Erwin escapes, he tries to hurt himself by hitting his head against a wall. The eyes of the black cat subsequently follow him everywhere. On the second narrative level, Zabel, now a young man and a soldier, sees another black cat, who evokes the first cat, floating on a piece of ice in the river. The cat is being attacked by the bored soldiers in the soldier's encampment. Zabel jumps into the river and saves her-an act that brings him in front of a court martial as a conscientious objector, since he subsequently becomes ill and is unable to fight. On the third narrative level, the judge who sentenced Zabel is visited by a friend of Zabel's who hands him a picture of a black cat and defends Zabel's actions that got him court-martialed. On the last narrative level, which frames the short story, the former judge lies in a hospital bed after a car accident that was caused by a black cat which appeared in the middle of a road. The picture of the cat in aggressive posture is the only thing that, aside from the judge, can be salvaged from the car, and is returned to the judge.

These two of Schnurre's post-war texts call for posthuman ethics by showing a carnophallogocentric world, in which men assert their dominance over nature through violent acts that result in the torture and killing of animals as an exercise of power. Carno-phallogocentrism is a term Derrida uses (see [3]) to describe a human society in which language and thought are dominated by man, and the powerful subject is a man who becomes synonymous with humankind. Furthermore, the conception of subject in this theory is based on the active mastering and ownership of nature as well as the sacrifice of the animal. These moments of violence against animals in the short stories follow a sacrificial logic, in which the animal's death establishes/reinforces man's position of power over nature. In a way quite typical of him, Schnurre offers two different discourses about the animal in these short stories: The discourse to which the human protagonists subscribe and which could be called carno-phallogocentric, and the discourse that is revealed as the plot develops, in which the animal subverts the first discourse. My reading of these moments reveals the need for ethics in which man no longer rules violently. In the following section, I first lay out the violent conditions of these carno-phallogocentric story worlds and then focus on salient moments of the texts in order to establish the sacrificial logic they put on display. Violence and the call to the reader for ethical considerations are intricately linked in the short stories. In order to arrive at posthuman ethics, it is necessary to analyze the role of violence first, since it is out of the violent encounters between human and Other that posthuman ethical consideration is born. Finally, I will draw conclusions about posthuman ethics I outline through the reading of Schnurre's texts.

\subsection{Living in a Carno-Phallogocentric World}

All the characters in Schnurre's postwar writing inhabit a world that follows rules of violence and power, and which can be labeled as carno-phallogocentric: Nearly all central protagonists are male, and their actions are motivated by an attempt to claim power in order to establish themselves as able subjects. Carno-phallogocentrism refers to a worldview in which, according to the combination of 
logocentrism and phallocentrism, the male subject is the center of society, dominates it and is in charge of all decisions, while the woman is excluded from participation in the discourse (compare [9], p. 111). Man becomes synonymous with human, and dominates the way of thought, discourse, and actions. The aspect of the "carno" in the term explicitly integrates the animal into these power hierarchies and refers to a carnivorous virility, as Carrie Rohman, a scholar of animal studies and post humanism in literature and culture, also elaborates: "Die Opferung des Tieres ist laut Dekonstruktion notwendig, um die Verleugnung des Anderen in Szene zu setzen, genau weil dieses Andere immer schon das Subjekt selbst ansteckt" ("The sacrifice of the animal is, according to deconstruction, necessary in order to stage the disavowal of the Other, exactly because this Other always already infects the subject." My translation ([10], p. 98). Two aspects are noteworthy in this context: The sacrifice of the animal is required; and the Other is always already part of the subject-which explains the need of the subject to disavow the Other.

In order to disavow any similarity between the subject and the Other (animal), the protagonists in Schnurre's short stories refer to the animals mostly as objects. Animals are no longer completely described; instead, we only read about parts of animals, such as "Wollrücken" (woolen backs) in "Das Manöver", where the majority of the story is dominated by this objectivized and functionalized view of nature and the Other. Similarly, we find animal descriptions such as "Fellknäuel" ("fur ball", [11], p. 81) in the narrative levels that invoke violence against the. These terms do not describe an Other that one can encounter, but rather a pure bio mass that is more object than subject. The linguistic logic in these terms reveals the speciesist thought system and concept of subjectivity to which the protagonists subscribe. It is obvious that no ethical obligations exist between human and "object"-animal. The terms used to describe the animals highlight the inherent worthlessness of the animal in the eyes of the human protagonists: They are described as "dumpfe[], nur ihrem Herdeninstinkt gehorchende[] Tiere" ("dull animals who only follow their herd instinct"5 [12], p. 121), or "hübsches Biest" ("pretty beast" [11], p. 77) — both terms "dull" and "beast" implying that the animal(s) being described do not have intellectual capacity and cannot be subjects in their own right. The term "dull", furthermore, does not only make a statement about the potential intellectual capacities of the animals, but also encompasses emotional capabilities, and suggests that these animals are also incapable of emotions, feelings of pain, or, most importantly, suffering. These descriptions of merely existing, but not living creatures (through their absence of emotional and intellectual capabilities) paint a world in which the animals are not part of ethical considerations, since they are seen as mere objects. Ethical obligations in this world, then, exist only between strong subjects, or between groups that have similarities.

The significant moment in these short stories is not the othering, objectifying description of the Other, however, but rather the conflict and violence the encounter with the Other triggers. The Other threatens the subject - by being Other, by undermining the subject's autonomy and independence, by its sheer numbers-and Schnurre's texts explore the dimensions of this threat. Violence is a tool that is employed in the short stories by a group or individual who feels threatened and/or powerless, and violence is the tool to achieve a sense of security. It is the moment of threat that calls forth violence-and ironically also opens up the possibility for seeing the Other not as object, but as a creature that calls upon ethical obligations, similar to the call to ethical behavior prompted by the face of the Other in Levinas' ethics, a call that acts upon us, without our choice. Before I turn to the ethical call and the face of the Other, I will address the violence that surrounds the moment of ethical awareness for the protagonists in Schnurre's stories, since it is exactly the violence triggered by the encounter that leads to the recognition of the limitations of exclusive ethics that do not account for Otherness.

Violence emerges in the short stories whenever there is a perceived threat to the autonomy of the strong (male) subject position as being in control and independent. In line with logocentrism, the protagonists in Schnurre's stories expect to be (making) the laws and rules, and the general

5 All of the translations of the quotes from Schnurre's short stories are my own. 
in "Das Manöver" is the perfect example of this. As a general and an embodiment of carno-phallogocentrism, he believes that man can master and possess nature. The way he sees nature is "ganz in die Funktionale gerutscht...und nur noch durch ihre Gebrauchsfähigkeit für militärische Spielaktionen definiert" ("only understood by its function...and only defined through its usability for military game plans", [13], p. 313). Since the general sees nature only as inanimate function, he assumes that it has to serve him and his purposes: indeed, he assumes he owns it. The delusion of commanding nature is pointed to early on by the general's annoyance "daß der Wind sich ihm widersetzte" ("that the wind resisted his will", [12], p. 119), which Manfred Durzak, a German literary scholar, describes as "Größenwahn militärischer Selbstüberzeugtheit, die selbst die Gesetzmäßigkeiten der Natur sich unterordnen möchte" ("megalomania of military belief in itself, which even wants to subordinate the laws of nature", [13], p. 314). The power the general holds over his soldiers leads him to assume that he should be able to control nature as well: "Die Schafe, befahl er mit bebender Stimme, hätten umgehend zu verschwinden, die verantwortlichen Herren sollten sofort die entsprechenden Befehle erteilen" ("the sheep, he ordered with shaking voice, had to disappear immediately, the responsible men should give the respective orders immediately", [12], p. 120). It becomes obvious that the general equates nature - the herd of sheep—with his own soldiers, since he assumes that the situation can be resolved with "respective orders".

Confronted with a flock of sheep during a military exercise, the general feels humiliated and ashamed, since these animals have managed to disrupt the activities of the men-and to make matters worse, this occurs in a strongly hierarchical setting in which the general is supposed to be in control of the situation. The disruptive appearance of the flock of sheep shames the general on two levels, which cause his violent reaction: On the one hand, he is ashamed that he cannot present his military exercise in an orderly way, as he had planned. This undermines his authority and status, especially since a group of high-ranking military officers has come to observe and now witnesses the failure of his exercise rather than his success. On the other hand, the cause of the disruption ridicules him, since it is not another human who outwitted him and caused his exercise to fail, but a group of "dull animals who only follow their herd instinct", as he sees it. It is especially ironic to look at the animal of choice for this disruption, since sheep are not traditionally seen as aggressive or threatening animals, but are rather as sacrificial animals in cultural constructions (compare [14]). Durzak comments on this ironic selection of a sacrificial animal as the animal who refuses to obey the humans:

Diese ganz in konkreter Beschreibung aufgehende Kurzgeschichte erweist sich als eine anspielungsreiche Textur, die mit der Bedeutung des Wortes Kadavergehorsam spielt und in ironischer Verkehrung gerade die Tiere, die sich üblicherweise blind zur Schlachtbank führen lassen, den Menschen überlegen zeigt. (This short story, written in a style of concrete descriptions, has a level of smart intertextual allusions which play with the meaning of

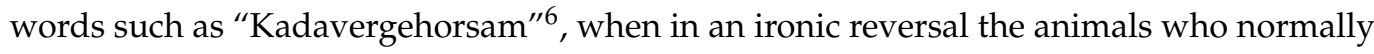
allow themselves to be blindly led to slaughter show themselves to be superior to the humans [13], p. 315).

The text uses the analogies between soldiers and sheep to portray the general as a laughable character on two levels: He is ridiculous because he assumes that he can command nature and also because the analogy between the soldiers and the sheep who defy his orders suggests that in the end, the general does not hold power over his soldiers, either. The threat the sheep symbolize in this moment is aimed at the general's authority, his masculinity, and his status as a subject all at once, and the presence of the sheep threatens the carno-phallogocentric world order. The general's anger is fueled by the danger the situation poses to his authority and power, which he clearly knows. In compliance with the carno-phallogocentric model, he attempts to resolve the embarrassing situation

6 Kadavergehorsam means literally carcass obedience, a type of blind and unquestioning obedience. 
by using the animals to strengthen his power instead: "sie sollten jetzt gefälligst mal achtgeben, wie man mit so einer Schafherde umspränge" ("they should pay attention now to how one deals with such a flock of sheep", [12], p. 121). His request to his soldiers to "pay attention" is supposed to make them witnesses to his act of masculinity and dominance. These scenes unveil the core of the general's worldview: He is a follower of a strict, hierarchical model of power, similar to the one described by historian Charles Patterson in Eternal Treblinka. This model posits humans as "separate from and morally superior to other animals...The relationship of humans to other beings became what it is today-one of domination, control and manipulation-with humans making life-or-death decisions concerning what were 'their' animals" ([15], p. 11). Accordingly, the general is used to exerting control and dominance-in the animal world as well as in the human world, in which his soldiers follow his commands closely, like herd animals. In his arrogance and with an attitude that betrays a sense of being used to getting his way, the general represents the carno-phallogocentric worldview, which is linked to explicit violence, as his response shows. Schnurre uses the sheep, a classical sacrificial animal, in order to subvert this worldview and in order to unveil the general's type of power as an illusion-a power that is based on hierarchies and assumptions about the value of life. The sheep's mirroring of the general's soldiers break down the species boundary and demonstrate through their disruptive presence that violent order cannot last, neither within nor beyond the species boundary. The general's decision to shoot into the mass of animal bodies in order to re-assert order (without success, as one may note) contradicts any ethical imperative. However, the juxtaposition of the lone individual who thinks he stands above events (and above reproach), like the general, with the mass of creatures (soldiers and sheep alike) points towards an ethical worldview in which no one is above another creature, and interconnectedness has to be acknowledged.

Beyond the threat to the general's sense of control and competence as general, the sheep also symbolize a rather real threat through their sheer mass. Beyond their "value" or lack thereof, the animals in "Das Manöver" are often described as a de-individualized mass, anonymous and more like a natural phenomenon than an Other: We find mass terms like "Tierflut" ("animal flood", [12], p. 122), "Tierströme" ("animal current", [12], pp. 121, 124), "Meer von Tierleibern" ("ocean of animal bodies", [12], p. 124) or "gegeneinander anprallende[] und ineinander verschmelzende[] Ströme[]" ("streams that impact each other and melt into one another", [12], p. 119). It is impossible for the reader to identify an individual animal. Instead, the animals are subsumed into a large mass which has neither individuality nor subjectivity. Through the sheer mass of the animals, the threat to the individual human is highlighted. Schnurre's text evokes paranoid, uncontrollable animal behavior with the semantic field of the flood or current, and simultaneously refers back to human masses like the mass movement during the Third Reich. These parallels are highlighted by the text's recurring comparison of the soldiers to the sheep. At the same time, if one compares living bodies to natural phenomena like floods, oceans, and currents, the individual disappears, and living bodies become instead a de-individualized threat which has to be dealt with, since the humans are faced with a "Flut von Sinnen gekommener Schafherden" ("flood of sheep flocks who are out of their minds", [12], p. 120) and with "über sie wegdonnernden Schafhufe" ("sheep hooves that thunder through and over them", [12], p. 121). The threat level is also emphasized by hyperbolic descriptions: One is only able to hear "tausend- und abertausendfache[] Getrappel der Schafhufe...das sich auf dem ausgedörrten Boden wie ein gewaltiger, drohend aufbrandender Trommelwirbel anhörte" ("the clap of thousands and thousands of sheep hooves...that sounds on the dry soil like a huge, threatening, rising drumroll", [12], p. 120). The impending doom for the humans in this landscape is highlighted when Schnurre writes: "Die Welt schien nur aus Schafen zu bestehen; so weit das Auge reichte, reihte sich Wollrücken an Wollrücken, die Panzer ragten wie zum Untergang bestimmte Stahlinseln aus dieser Tierflut hervor" ("The world seems to be made of sheep; as far as the eye can see, wool back is lined up next to wool back, and the tanks stand out of this animal flood like steel islands doomed to fall." [12], p. 122). In this moment, an ethical perception of the Other (in this context of the sheep) as vulnerable and deserving of consideration is stalled by the descriptions of animals (or 
Others) as threat and mass, since it enhances the vulnerability of the human subject. On the other hand, the mass also carries the idea of Deleuze's and Guattari's "pack" and multiplicity, which makes hierarchies impossible and contains anti-oedipal tendencies (see [16], p. 52). According to this theory, a multiplicity moves away from hierarchical concepts and instead offers a dynamic whole where there are no clear hierarchies-and thus no clear power relations within the mass. In this function, the mass can be seen to represent a threat to authority, as the helplessness and ultimate failure of the general to dominate Others also proves. ${ }^{7}$

Beyond the possibility of threat signified by the animal, the value of animals for the protagonists within the carno-phallogocentric world of the short stories is reduced to providing the latter with an opportunity to establish themselves as superior and potent beings and claim a sovereign-like power over life and death. The animals are in a state of what Agamben would call "bare life" - their lives have no value in the human community in which they live. This position of bare life is relevant in terms of ethics, since it is the life that politically and socially is outside of the community, and whose death thus does not matter. Similar in aspects to the figure of Agamben's homo sacer, this life can be killed without the act's designation as murder (compare [17]). This creates a zone for life outside of ethics-life that does not demand ethical consideration. The behavior of the protagonists towards the animals in Schnurre's short stories shows that for them, the animals do not hold a place in ethical considerations, but rather are sacrificed as a way for the human protagonists to establish or cement their power. While sacrifice and sovereign power drive the actions of the protagonists in Schnurre's two short stories, the logic of the story eventually undermines this sacrificial logic and positions the animal well within the realm of ethical consideration, as becomes especially clear in the story "Die Tat". While the general in "Das Manöver" responds to an open challenge of his world order (and his sovereignty-at least on the battle field), the sacrificial logic in "Die Tat" is rooted in the area of potential power the protagonists hope to achieve by sacrificing the Other.

In "Die Tat", the logic of threat, sacrifice, and the attempt to empower oneself through sacrifice becomes especially clear. There are two distinct attacks on animals in the stories: The one by the children in the earliest plot line, and the unprovoked attack of a huge black cat floating on a piece of ice in the river in the second timeline, during WWII. The first attack on an animal in "Die Tat" is the central moment of violence, since it introduces the theme of the black cat which ties all plot lines together. In this scene, the children attack a black cat that they perceive as a threat to their (illusionary) sense of a strong, autonomous male identity-similar to the general in "Das Manöver". Erwin and Zabel, the two pre-teen boys, encounter the cat unexpectedly on an afternoon. Unlike the general in "Das Manöver", the two boys, due to their age, lack any real power in society. The lack of real power in society, however, does not mean that the boys do not strive for power and strength, and their readiness for violence underscores this. Accordingly, Erwin, the child who starts the violence, is described as "herrschsüchtig, stumpf" and "skrupellos" ("bossy, blunt, and ruthless", [11], p. 79), and his ruthlessness gains him a certain power over the younger boy. The ruthlessness of the children and their willingness to use violence in this scene are significant, since they mirror the discourse of violence that the SS used during the Third Reich to train the Hitler Youth to use violence against animals and humans alike in order to achieve a "technokratischen Distanziertheit" ("technocratic detachment", [14], p. 167). In this scene, Schnurre unveils the mechanisms of violence that drive genocide. The torture of the cat entails a dimension beyond "mere" violence against animals, since it also references the violence used against (human) Others during the Third Reich. Significantly, the cat is not simply described as Other in the scene, but explicitly as a threat: After suspecting a "tiger" ([11], p. 80) and thus a dangerous animal, the cat is revealed only bit by bit, and in threatening descriptions: "Schnurrbarthaare wie Stahl und zwei wütend gefletschte Zahnreihen...und setzte wohl gerade zum Sprung an" ("whiskers like steel and two angrily bared teeth...and was apparently getting ready to jump", [11], p. 80). The bared

7 I will come back to this subversion when I discuss Schnurre's narrative structure of Unterkellerung in Section 2.1. 
teeth point to danger, and the whole description is reminiscent of a dangerous demon. Even though this text only presents one individual animal and not a whole pack, as in "Das Manöver", the initial description of the cat with steel whiskers, bared teeth and ready to jump seems to symbolize a real threat to the children. This threat is underscored by the cat's black color which, in Western cultures, links her with symbolism as the harbinger of superstitions from bad luck to the devil incarnate. She scares the children so that the older boy "prallte zurück" ("recoiled", [11], p. 80). This challenge to the masculinity and power of the older boy leads to his demand: "Die ziehn wir ab!" ("We're going to show that one!" [11], p. 80). The subsequent torture and murder of the cat is a direct result of her threatening the imaginary position of masculinity and power in which the older boy sees himself. The fact that the cat is female and happens to be pregnant only further intensifies the challenge to his masculine subjectivity. However, it is also this moment that leads Zabel to attack his friend, stop the violence, and subsequently change his attitude towards the Other. The awareness of the ethical obligation towards this Other's life is born in the gory moment in which he notices that the violence was not really directed at a powerful Other, but a precarious and vulnerable life-a pregnant cat.

The second attack on the cat floating on the river, executed by the soldiers stationed at the Dnjepr, echoes the first one. Unprovoked, the soldiers respond immediately to its appearance with violence and aggression:

Der Fluß führte Treibeis, und plötzlich kommt da auf ner irrsinnig rotierenden Scholle eine Katze, eine riesige schwarze Katze, angefahren. Gleich wurden überall Konservenbüchsen, Holzscheite und Schneebälle bereitgelegt, und wo nun immer das verängstigte Tier ne Schar johlender Landser passierte, da brach so ein Hagel von Wurfgeschossen über es rein. (The river carried drift ice, and suddenly a cat, a huge black cat approaches on a crazily spinning floe. At once, cans, logs and snow balls were readied, and wherever the frightened animal passed a group of hooting privates it was met with a hail of projectiles [11], pp. 76-77).

This cat is turned into a kind of "tool" for establishing dominance and power for the privates: In the logic of sacrifice and sovereignty, the privates only become subjects by sacrificing the Other. The need to sacrifice in order to gain power is based in the historical context of this scene: The setting of the attack on the second cat is an army camp close to the Dnjepr in winter 1943 (see [11], p. 76), where the Wehrmacht was withdrawing after their failed offensive against the Soviet Union. ${ }^{8}$ The failure of the offensive threatened the status of the soldiers: They had to accept that they were "inferior" to the opposing army and not the powerful ones in this situation; a realization that, subscribing to a phallogocentric worldview, threatened their masculinity and made them feel inadequate. The cat is a welcome distraction to the soldiers, and it also offers them an opportunity to enact a little bit of power and thus make them feel powerful again, at least for a few minutes. This explains the immediate aggression they display toward the animal and that is expressed in the hail of projectiles. That the attack is accompanied by "johlen", hoots and cheers, reveals the soldier's lack of compassion. The description of the scene subverts the sacrificial model of violence which is rotted in the sovereign power over life and death and requires eliminating threats to one's power: Unlike the first time when the cat facing the children is described in threatening terms, this cat now is described as "verängstigt", frightened. This change in adjectives from threatening to precarious underscores the sacrificial logic as an illusion: Killing a weak, frightened being is not an act of power. In addition, even in the first cat attack, carried out by the children in "Die Tat", was the inversion included when it turns out that the cat was pregnant. In this way, the violence against the cat was not only amplified, but at the same time it became a destruction of life that could not possibly be threatening (i.e., the kittens).

8 This fight was part of a larger failure of the summer offensive. The Battle of the Dnieper (1943) was among the costliest operations of the war, with high casualties on both sides. It marks the moment of the large fallback of the German troops and general sense of loss of fighters, weapons, and sense of morale among the Wehrmacht troops. 
In this context, the title of the short story becomes relevant: Translated, "Tat" means act, deed, or even crime. Yet it is unclear which element or "deed/crime" in the story the title refers to. There is the "official" crime of supposed conscientious objection for which Zabel is convicted-Zabel's deed: Because Zabel jumped into the river in winter during war time (to save the cat) and thus caught pneumonia, he rendered himself unable to fight. For this, he was court-martialed and convicted. However, this "crime" saved the life of the black cat trapped on the river and could, in ethical terms, also be read as a good deed. If the title is read in this light and the "act" refers to the punishable act under human laws, it is striking that Zabel is punished for saving a life, which points to a non-ethical world. The "act" in the title could also refer to the encounter with the pregnant cat, the act being the killing of this particular cat and its kittens, which haunts the rest of the story-the children's deed. Since this scene is described in increasingly gory terms, the title would then have to be understood as a crime-yet not a crime in the legal sense, but in the moral sense, since the torture of the cat clearly got out of hand with the children's mutilation of the carcass. In both of those scenes, the act in question is inextricably connected to the animal sphere. The third act that the title could refer to is the judgement the judge passes on Zabel for jumping in the river (and, indirectly, for saving the black cat's life)-the judge's deed. In this case, the incompatibility of ethical action with war-time legislation would be highlighted. Animal life and human life are inextricably intertwined in the act/deed/crime. The oscillating meaning of the title thus points to the interdependency of human act and animal life, and to the juridical aspect of it: An act is never just a disconnected act, but is interwoven with responsibilities, obligations, and consequences. In the oscillating meanings of the title, Schnurre already points to the theme of interconnectedness that lies at the core of posthuman ethics, and which his short stories play out through a model of apparent power and violence and its inversion.

\subsection{Posthuman Ethics: The "Unterkellerung" (Hollowing out) of Speciesism}

The failures of human protagonists to subjugate Others serve to show the limitations of a speciesist conception of subjectivity and action, and can therefore suggest a different conception of relating to an Other-indeed, a posthumanist one that is not limited by the inherent hierarchies that accompany humanist conceptions. Schnurre's short stories employ the strategy of subversion of human power to undermine anthropocentric discourses in a direct confrontation between man and (individual) animal. Since his short stories, on the surface, mirror carno-phallogocentric conceptions of reality, he is able to show their limitations and the violence they create, and then offer an alternative by including a sub-level to hollow them out. He writes in his commentary "Kritik und Waffe" (1959) that "die Kurzgeschichte, bei aller scheinbar realistischen Schreibweise, unterkellert ist von einem wahren Fallgrubensystem" ("The short story, even though it seemingly employs a realistic writing style, is hollowed out by a system of traps." [18], p. 390). This system of traps leads to an "Unterkellerung" (Hollowing-out) — a metaphor for a system of empty spaces and places which exists just beyond the surface of the text. Unterkellern means that everything has a deeper level, and the reader cannot take the surface level of the text (like the motivations and the worldview of the protagonists, for example) at face value or as truth. This system unsettles or even reverts power hierarchies and false assumptions about the capabilities and the value of Others. The subsequent plot developments in his short stories, by means of "Unterkellerung", present a different discourse than the one supporting the human-animal-hierarchy, by inextricably entwining human guilt and suffering with the animal sphere. Schnurre's stories unseat the human and question his supremacy by juxtaposing the suffering gaze of the animal with the actions of the human. The question of guilt and the "Tat", the actions/deeds of the humans, whether criminal or not, problematize the hierarchy and raise questions about delinquency, agency, power, and victimhood. In this way, Schnurre's short stories point to posthuman ethics of interconnectedness and obligation which shows similarities to the ethics of Levinas as well as Butler, yet goes beyond both by tying them explicitly to the animal world. In order to arrive at such ethics, it is first important to "hollow out", unterkellern, the carno-phallogocentric worldview held by nearly all human protagonists in the short stories. This Unterkellern is a necessary step in order to arrive at 
posthuman ethics, since it demonstrates the hollowness of a subject position that thinks itself separate and above Others. It is only through the process of recognizing this subject position as hollow and acknowledging that violence destroys both victim and perpetrator that a posthuman way of ethically relating to the Other can be found.

The use of inversion is a major method for Schnurre to achieve his Unterkellerung (hollowing out) of the presented carno-phallogocentric discourses. This is most visible in "Das Manöver" and is already inherent in the descriptions of the protagonists who subscribe to a strict, hierarchical model of power: Even before the sheep are introduced into the narrative, the general is ridiculed for thinking he can command the powers of nature (see [19], p. 170), such as the wind, and this intensifies when the animals are introduced: "Ein maßloser Zorn stieg in ihm auf; ihn, der sich in zwei Weltkriegen und dutzenden Schlachten bewährt hatte, ihn solle dieses Gewimmel dumpfer, nur ihrem Herdeninstinkt gehorchender Tiere der Lächerlichkeit preisgeben?" ("A boundless anger welled up in him; a herd of sheep, mindless animals who only follow their herd instinct, should ridicule him, who proved himself in two world wars and dozens of battles?" ([12], p. 121). The reference to the world wars and battles, which gave the general his position of power, highlights the contrast between having power in a given context and illusionary phantasies of superiority over all forms of life. It also reveals the power the general holds in any moment as an illusion-yet one that sets him apart from his environment, and makes him prone to committing violence. The general's frustration and powerlessness serve to unveil speciesist power structures as false mechanisms. In his panicked response of entering the flock with his jeep, he mimics the irrational behavior and panic previously ascribed to the sheep (see [13], p. 314). This way, he takes on the same position as his worldview ascribes to animals in terms of agency: he is no longer in control of his actions. The mirroring of human actions in those of the sheep becomes a main stylistic device which, piece by piece, breaks the anthropocentric worldview and exposes it, to the eyes of the reader, as laughable. It also serves to question any sense of power the human protagonists think they have-or attempt to claim. The classical power hierarchies are inverted, and the animals, through the ironic treatment of the human characters, are revealed to be the superior ones.

Schnurre uses Unterkellerung to invert power positions between human and animals and thus reveals power to be, ultimately, hollow. In order to subvert and break the hierarchical power structure between human and animal, Schnurre's texts repeatedly pose the questions of guilt and agency. To answer these questions, one must take a closer look at the turning points of both stories, namely the moment in which the animal gaze meets that of the human. The central role of the gaze in these short stories evokes an ethical obligation in the Levinasian sense: For Levinas, the face of the Other, its proximity in the direct encounter, is also the central moment for the ethical obligation: "The face imposes on me and I cannot stay deaf to its appeal, or forget it,...I cannot stop being responsible for its desolation...Thus, the presence of the face signifies an irrefutable order-a commandment- that arrests the availability of consciousness" ([20], p. 32). The ethical call that the Other's face signifies for us, in Levinas, binds us to the Other and does not allow the moment of choice. While the aspect of the face and the encounter in Levinas' ethics lend itself quite well for inclusive ethics, as Butler also points out (see [8], p. 140), Levinas' ethics remain bound up in a Judeo-Christian tradition and do not extend beyond its context (or beyond the species boundary, for that matter). Using the animal encounters in Schnurre's short stories enables us to question this limitation and see whether ethics based on proximity, and an encounter focused on the face and especially meeting the gaze of another, cannot go beyond the restrictions of Levinas' concept and encompass all Others. Whereas Levinas claims a clear difference between the human and the animal face, Schnurre's text challenges the notion that there really is a difference and claims for the animal face the same importance as for the human face.

The animal gaze as well as the animal's face is predominant in both stories and bears witness to the actions that are carried out. The animal face reaches significance at the turning moment in "Das Manöver" when a huge ram comes face to face with the general and confronts him. In a reversal of the traditional roles, the ram becomes the sovereign, and the encounter between ram and general explicitly negotiated the limitations and opportunities of ethics by unterkellern (hollowing out) the emptiness 
of exclusive ethics-and the famous sixth commandment that is echoed in Levinas' ethics as well ${ }^{9}$. Differently from the other animals, the mass of sheep, this animal, and especially its face, is described in greater detail. The encounter between the general and the ram is central to the poetic subversion of anthropocentric, violent power. The general's inability to control the sheep comes to a head when he panics and drives his jeep into the flock. The "Tierflut" (animal flood) is threatening to wash away his dominance, and he reacts with violence to re-establish order and end his embarrassment. However, the order that follows looks different than what he had planned: Around the crashed car, the sheep withdraw and leave an open space in which the general has to confront a "riesiger, schweratmender Widder" ("huge ram that was breathing heavily", [9], p. 122), the animal he hit while randomly shooting into the mass of bodies before. The situation unfolds like a classic showdown: the general on one side, the ram on the other: "Der General wusste sofort: dieses Tier hatte er vorhin verwundet, und diesem Tier würde er sich stellen müssen" ("The general knew immediately: this was the animal he had wounded earlier, and this was the animal he would have to face", [12], p. 123). The formulation used here, "sich stellen müssen", that the general has to "face/face up to" the ram, has two different functions: It marks the instantaneous knowledge of the general's guilt, but it also introduces the shifting power relations between man and animal in this moment: The person who has to "face" or "face up to" someone often does not hold power, and the power lies with the Other who has to be faced-in this context, the wounded animal. It is significant in this context that, for the first time in this story, Schnurre shifts his description of the textual animals as a mass to the description of an individual animal, a unique ram. This shift also comes with a change in the cultural meaning of animals: Whereas sheep are traditionally only sacrificial animals, the ram, even though also a sacrificial animal, symbolizes a political leader, strength and life force ([21], p. 484). Furthermore, the shift in focus to the ram, a male animal, also signifies a change in the gendered constellation. Since the general subscribes to a phallogocentric worldview, only a male animal can challenge him to "face up" to him.

The initial banality of the situation and the anonymous mass of the animals, the "Tierflut", suddenly turns into something different when the general is confronted with the gaze of this one animal-not a faceless flood of wool, as before, but an Other who has a face. The ram functions in the same way here as the singular, unique cat (not "a/any cat") in Derrida, and also as the "anomalous" at the border of an (animal's) pack functions in Deleuze's and Guattari's theory of "becoming" (see [15], pp. 332-37). The ram is able to confront the general because he is not just any animal (or the undistinguished mass of animals from before), but rather this single unique ram. In this moment of confrontation, in the exchange of the gaze between human and animal, the general recognizes himself in the Other. However, he does not recognize himself as his role or status (i.e., general), since he "war jetzt kein General mehr" ("was no longer a general", [12], p. 123) but rather as a part of precarious life: powerless, connected to other life, and utterly vulnerable. As such, the text describes him as "jenseits all seiner militärischen Autorität [reduziert] auf seine kreatürliche Schwäche und Angst" ("beyond all his military authority [reduced] to his creaturely weakness and fear", [11], p. 314). His realization is supported by the general's appeal to the laws of life and death, the laws of compassion, which also lie at the core of Levinas' ethics, and which in the story are expressed by the general as follows: "Er darf mich nicht töten, er darf mich nicht töten" ("he mustn't kill me, he mustn't kill me", [12], p. 123). This is the moment of ethical awakening for the general, appealing to the sixth commandment, the moment in which he understands that acting has to go hand in hand with ethics, but it comes too late. Reduced to bare life, stripped of all power, the general takes the role the animal previously held: He stands outside of the ethical realm, and the Other, here the ram, holds no ethical responsibility towards the general. Similar to the black cat in "Die Tat", which turns into a kind of sovereign for the protagonist, the ram functions as the sovereign for the general and takes his life.

9 The sixth commandment is "Though shall not kill". 
The reversal of the sacrificial structure is not without irony, and shatters the worldview of the human onlookers:

Niemand hatte geahnt, daß der General sich in Lebensgefahr befunden hatte. Einige der Panzerbesatzungen und die Offiziere...hatten zwar, als der Jeep umgekippt und dann plötzlich der Widder auf den General losgegangen war, den Eindruck von etwas Ehrenrührigem und Peinlichem gehabt, aber auf die Idee, der Widder könnte dem General gefährlich werden, war niemand gekommen. Die Offiziere fühlten sich daher, als der General sich nicht wieder erhob, etwas merkwürdig berührt. (No one had suspected that the general was in danger of his life. Some of the tank troops and the officers had had the impression of something dishonorable and embarrassing in the moment when the Jeep overturned and then the ram suddenly attacked the general, but it did not occur to anyone that the ram could become dangerous for the general. Thus, when the general did not get up again, the officers felt strangely moved [12], pp. 123-24).

The inconceivability of the life-threatening danger, coming from an animal, underlines the lack of subject position and power of the animal in the human world. The challenge of the ram, charging at the general, is reduced to something "dishonorable and embarrassing" — not perceived as something possibly dangerous, and yet it is exactly this challenge that dooms the general. What also becomes clear in this moment is that everyone, independent from their social status or rank, can be reduced to "bare life" and can become vulnerable, even though bioethics often defines vulnerability mostly for marginalized groups that have a higher likelihood to "face a significant probability of incurring an identifiable harm while substantially lacking ability and/or means to protect oneself" (see [22], p. 13). The fact that this can happen to anyone, even a general, as the onlookers in "Das Manöver" have to witness, explains that they feel "strangely moved" - they have to acknowledge their own position as precarious life, a "strange" feeling for the onlookers who subscribe to the same discourses of strength and power the general subscribed to.

Similarly, in "Die Tat" the animal's gaze as leitmotif is used to question the actions of all protagonists and thus achieves the status of a witness and judge of ethical behavior. The repeated insistence on juxtaposing the animal's gaze and the human in the story gives the cat a role larger than just one animal's life, and enables both cats, through the repetition of their staring gaze, to become the ethical conscience for all who encounter it. The first animal gaze we encounter in "Die Tat" is indeed the gaze of the pregnant cat, about to be tortured to death by the two boys. After first introducing only her "schwarzer Kopf, korngelbe Augen" ("black head, eyes the color of grain", [11], p. 80), the description turns to her suffering face: "'s [sic!] war wie ein Alptraum; immer wieder tauchte dieses gefolterte Tiergesicht in dem Eimerrund auf, immer wieder wollte es hoch und ans Licht, und immer wieder riß es uns in seiner zerschundenen Hilflosigkeit zu neuen und grausameren Peinigungen hin" ("It was like a nightmare; over and over the tortured animal face appeared in the round of the bucket's opening, again and again it wanted up and into the light, and again and again it carried us away to new and crueler torments in its maltreated helplessness", [11], pp. 80-81). The cat and her gaze have two functions in this context: First, she bears witness and reflects back on the role the humans play in this short story, and describes the world they create as a "nightmare". Second, her presence and her face proclaim an obligation to posthuman ethics that goes beyond Levinas' conception and intertwines ethics and violence. In this, she shows similarities to the other cats in the short story, and I shall come back to this aspect shortly.

The role of animal witnessing, also in relation to war atrocities, has been examined by cultural animal studies scholar David L. Clark (see [23]), but it has otherwise not yet received a lot of attention. The gaze of the tortured cat "dispossesses", as Clark formulates, the children, and the short story undermines in this very moment of animal witnessing what it means to be human, and whether species belonging is sufficient for ethics and humane (not human) actions. Derrida writes that "As with the bottomless gaze, as with the eyes of the Other, the gaze called 'animal' offers to my sight the abyssal limit of the human: the inhuman or the ahuman, the ends of man, that is to say, the bordercrossing 
from which vantage man dares to announce himself to himself, thereby calling himself by the name that he believes he gives himself" ([24], p. 12). As such, the gaze of this pregnant cat becomes the abyss for both children in which they confront their own animality-and fail to establish themselves as "human(e)" in an ethical way. The children do not to feel an ethical obligation, but in contrast are inspired to even greater violence by the "tortured animal face" and the "maltreated helplessness" of the pregnant cat. This description, with its focus on precarious lives being destroyed without regard to ethical obligations, undermines the very superiority and concept of "the human". What the children discover in themselves is indeed the inhuman in a very literal sense: They act as if "jedes der tausend und abertausend Jahre, die seit dem ersten Schritt von der Bestie zum Menschen vergangen sein sollen, war eine Lüge gewesen" ("each one of the thousands and thousands of years which have passed since the first step from being beast to becoming human was taken had been a lie" [11], p. 81). The moment of the children's "devolution" to the status of the "beast"10 contradicts the Levinasian conception of being human, as Clark summarizes it: "According to this configuration, 'Man' is exemplarily free from the blind force of nature, whereas animals are immersed in the liveliness that constitutes their animated existence to the precise extent that it deprives them of their liberty, their ability to 'question', to anticipate both their 'own' death and the death of another" ([25], p. 181). Schnurre's text turns this configuration upside down by aligning the children with the "blind force of nature" (and worse, as the word "Bestie" suggests) and juxtaposes their actions with the gaze of the cat and the repeated reference to her face, which both bears witness to the moment and also demonstrates, in its suffering, an awareness and anticipation of her own impending death. At the same time, it becomes obvious that violence, even though used against the Other, destroys both sides in the context: The children, by destroying the cat, destroy their own humanity—and thus themselves.

The animal as witness to the human's actions, but also to the status of the human as human(e) evokes in some ways Levinas' text "The Name of a Dog or Natural Rights" [26]: In this autobiographical account, Levinas reflects on the encounter between a group of Jews interned in a Nazi concentration camp with a dog named Bobby, referred to as the "last Kantian". For the interned Jews who, according to Nazi discourse, were seen as subhuman or even non-human, Bobby offers the opportunity to confirm their humanity: "For him, there was no doubt that we were men" ([26], p. 153). The dog in Levinas' story plays a central role as a witness to man's humanity—or inhumanity. By confirming the human status of the interned Jews, he attests at the same time to the inhuman behavior of the guards. The cat in Schnurre's short story does not, as in Levinas' "The Name of the Dog", confirm the humanity of the human protagonists, like the encounter between the Jews and Bobby does, but rather confirms the inhumane nature of their actions. Like Bobby, Schnurre's animals highlight the limitations of a discourse that values life according to a hierarchical structure. It is significant that both of Schnurre's short stories also contain violent plot lines that are set clearly after 1945: this demonstrates that these discourses outlived the Third Reich and are still very much present.

The second function of the cat's face I pointed to above is connected to her status as witness, and is closely aligned with precontractual (i.e., not requiring reciprocity or a "contract") calls to ethical obligations, as Butler would call it. Aligning with Levinas, this ethics is one where the Other has priority over me, and where reciprocity is not required as the basis of ethics. Similar to Butler, this ethics insists "upon a certain intertwinement between that other life, all those other lives, and my own-one that is irreducible to national belonging or communitarian affiliation" ([8], p. 140). Yet unlike both Butler and Levinas, these posthuman ethics are entangled with explicit moments of violence and are born out of the violent encounter with the Other. In order to achieve posthuman ethics, one has to recognize oneself as a (potential) perpetrator-and as the inhuman, and recognize that ethics based merely on human-centered principles are insufficient. This recognition first happens for the reader

10 Please note that the word "Bestie" in German is not synonymous with animal, but rather belongs to the semantic field of ruthless, cruel, violent creature. The English term "beast" in the translation suggests an alignment of the cruelty of the children with the animal world that is not entailed in the German word "Bestie". 
during the violent and repulsive description of the torture scene, and second on the level of plot for Zabel, who, upon discovering the dead kittens in the carcass, recognizes his inhumanity. The short stories hold that the call of the face of the Other alone, as Levinas' ethics suggested, is not enough to create ethical actions. In Levinas" thinking, "warfare" and "violence" cannot be carried out against an animal due to the lack of a face (in the ethical meaning) (compare [25], p. 183). According to this reading of Levinas, one cannot say that the cat in the short story is subjected to "warfare" or "violence"; however, she is deeply entangled in the war context through the historical positioning of the human protagonists, and she clearly falls victim to excessive violence that does not only end her own life, but also that of the kittens she was carrying. The actions of the children demonstrate a lack of compassion towards the animal, since they keep beating and mutilating the animal body until Zabel discovers the bodies of the kittens. This continuing violence demonstrates the limitations of anthropocentric ethics, as Clark describes it: "The sixth commandment has a double force in culture: not only, as Levinas contends, as the interdiction that commands obligation to the human Other, but also as a tacit permission to think the animal Others, and all the living things for which the 'animal' comes zoomorphically to stand, as lying 'outside' the neighbourhood of call and response" ([25], p. 186; italics in original). When they mistreat the animal, the boys follow this tacit permission that the animal Other is outside of the "neighborhood of call and response", i.e., is positioned outside of the realm to which one has an ethical obligation. Since the sixth commandment in the Judeo-Christian tradition is conventionally interpreted as not including animals, the "call and response" falls away, and the children can defy the ethical obligation of their sovereign conscience, which the face of the Other would normally trigger (see [20], p. 33). These children will be the same ones who will serve under National Socialism which, as a technocracy, required acts of violence against weaker Others (compare also [14], p. 167). It is thus no coincidence that those children defy the ethical obligation of the face, and instead take it as a call for violence because the face is just too different or "other".

However, the incidental death of the kittens, life at its most vulnerable, shocks Zabel into awareness - an awareness of the violation of precarious life, which causes him to first attack the older boy, Erwin who remains lost in his fit of violence, and when Erwin escapes, to attack himself (compare [11], pp. 81-82). It is also this younger boy, Zabel, who will later refer to this childhood act as "Mord" ([11], p. 83)-murder, signaling with this word choice that he considers the animal to be part of an ethical framework, and a subject that can, indeed, be murdered-and not simply perish. His self-destructive tendencies immediately after the murder of the pregnant cat and the fact that he sees the cat everywhere afterwards, speak of an awareness of the loss of his humanity, and of an awareness of his transgression of an ethical boundary when he tortured the cat. The boundary he transgressed could be compared to Derrida's idea of the "right of a guest" he develops in The Beast and the Sovereign [27] when reading D. H. Lawrence's poem "Snake". As life that was already there-and, as Butler would put it, in the unchosen character of modes of cohabitation or being in the world (see [8], pp. 144, 146), the cat in the bucket can, following Derrida's steps, claim the law of hospitality: "He [in Derrida's text the snake from the poem] is the first comer, and whether or not he wants to or might kill me, I owe him, I ought not to kill him, I ought to respect him. He is therefore a guest" ([27], p. 321). In this law of hospitality, the "guest" - the one that comes before, the unchosen creature (animal or human alike) that cohabits the earth with us, deserves some respect-a respect that has to be given regardless of whether that creature poses a threat or not. As critical theory scholar Judith Still writes about hospitality in Derrida: "Men need to offer hospitality to others (not only semblables, our like) in order to achieve humanity" ([28], p. 246; italics in original). The description of the children in Schnurre's short story as "Bestien", beasts and brutes, demonstrates how their violation of the right to hospitality of the cat strips them of their humanity.

The black cat saved from the river acts similarly as a witness to Zabel's re-narration of his childhood transgression, which he tells to a nameless friend after saving the cat from the river. She is a constant reminder of the broken law of hospitality, indeed an ethical law: "Zabel schwieg...Die Katze hatte aufgehört zu schnurren; ihre Augen phosphoreszierten, sie schienen lidlos zu sein, so starr wirkte 
ihr Blick" ("Zabel fell silent...The cat had stopped purring; her eyes were phosphorescent, they seemed to be lidless, her gaze was fixed", [11], p. 80). The transfixed gaze of this specific cat, listening to Zabel's story alongside the humans, embodies the claim for the need of posthuman ethics and forces not only awareness, but repeated acknowledgement of the Other. His awareness is what links Zabel to the cat he saves from the Dnjeper river during war-an awareness of the interconnectedness of precarious life, and the knowledge that violence or even non-action would make him guilty: "Ich begriff, daß auch im Grauen, auch in der Angst eine Forderung steckt; die Forderung, etwas zu tun. Etwas, das das Grauen beschämt" ("I understood that even in terror and fear there is a demand to do something. Something that puts the horror to shame", [11], p. 83). This demand or challenge to do something is the call of posthuman ethics. Schnurre's short story suggests, though, that the call for ethics and an understanding of it can only come after the violation of the Other. Derrida writes similarly: "Of course, ethics as such, the formalization of ethics clearly appears after the fact, i.e., after the transgression of ethics, after the murder" ([27], p. 328). Only through the horror was Zabel able to understand that what was required was not his death or atonement (compare [11], p. 82), but rather an ethical approach to any Other, including animals, which he follows when jumping into the Dnjeper in winter at the risk of his own life to save the black cat.

The demand as an ethical challenge to act is collected by the subsequent cats in the short story that end up haunting the person who denied the right of the guest the first time. Referring to the time after killing the pregnant cat, Zabel states: "Nur eins ging nicht weg: Die Katze...Wenn ich aufwachte, saß sie an meinem Bett. Wenn ich schlief, war sie in meinen Träumen...sie blieb; blieb, blieb und starrte mich an" ("Only one thing didn't disappear: The cat...When I woke, she was sitting at my bed. When I slept, she haunted my dreams...she stayed; stayed, stayed und stared at me", [11], p. 82). In this moment, the cat, the real, pregnant, killed cat turns into an uncanny figure, not a real cat anymore, as also signified through the repetition of the word "blieb" (stayed). The real cat is transformed into a symbol that points beyond the life of the pregnant cat and her kittens and embodies posthuman ethics and the ethical "primeval sin" of the murder that brings awareness to Zabel. The face of the animal, as a leitmotif, highlights the law of hospitality the children broke and serves as a reminder of the violation that haunts the human protagonists throughout the narrative. The reversal of power structures subverts or "hollows out" the narrow meaning of human guilt or innocence, which Schnurre scholar Mathias Adelhoefer (compare [29]) sees as central. Instead, the reversal now posits the animal as the sovereign: "The beast becomes the sovereign after having been ...the target of an attempt on his life, an act of hatred on the part of man" ([27], p. 325). The Other, the cat, gains power over the life of the human protagonists through their transgression against her. The cat takes on the role of witness for the remainder of the short story: She stares at Zabel from the piece of ice, more of a symbolic, uncanny reminder than a real cat, and years later her gaze in the picture causes the judge's accident as well. The guilt of each character-a guilt that is based on thinking of oneself as superior and acting without compassion-is symbolized in the uncanny recurring presence of the black cat. In this way, posthuman ethics emerge ex negativo. Posthuman ethics are ex negativo because we see very few to no deeds in the stories that subscribe to posthuman ethics. Rather, Schnurre's stories show us how and where posthuman ethics can emerge, and why a narrow understanding of ethics that excludes Others is harmful —not only to those Others, but also to those who are within the ethical community. In line with Schnurre's writing style of Unterkellerung, posthuman ethics are found in the spaces that open up below the surface of the human protagonists' thoughts and actions. It is the abyss that shows the inhuman. While the protagonists clearly act without compassion and not in an ethical way, the recurring presence of the cat declares them guilty and serves as a reminder that an ethical law was broken by their deeds. The black cat bears witness to the inherent potential of all humans to become perpetrators of violence. The gaze of the innocent, tortured creature charges the protagonists who eventually must surrender to this accusation. The gaze of the cat becomes a reminder of the guilt for which one cannot atone (compare [29], p. 76). 


\section{The Emergence of Posthuman Ethics}

Both short stories address how anthropocentric ethics will ultimately fail because they are inextricably bound up in speciesist discourse and humankind's sense of entitlement and domination over the Other. It is the humanist, exclusive power structure and hierarchical subject conception that enables violence. ${ }^{11}$ The failure of anthropocentric ethics declares the guilt of humankind, as Zabel's friend, the nameless messenger who delivers the cat story, tells the judge: "Schuldig sind wir alle; da liegt der Unterschied nicht. Was wir aus unserem Schuldgefühl machen, wie wir uns einrichten mit ihm—darauf kommt's an" ("We are all guilty; that's not where the difference lies. What we make of our guilt, how it has an impact on us-that's what matters", [10], p. 75). Interestingly, this statement, which includes the judge as well as the one who speaks it, comes from someone who, in the story, has not committed any violence against Others. However, he implies himself as well as the judge in the statement as participants in a world that uses violence in order to gain power and/or establish a (false) sense of security. In both stories, the gaze of the animals confronts us with this fundamental truth about speciesism as well as with the question of guilt that is connected to it. The animal gaze reflects the actions of the human, becoming a mirror for the human being, as Agamben describes it, and induces guilt. Schnurre's short stories uncover the fact that our social hierarchies are inextricably bound up in structures of violence, and that this violence turns every Other into a possible target, outside of ethical considerations. The subject model that is based on an anthropocentric worldview leads to the harm and destruction of the Other.

The posthuman ethics that emerge in the short stories ex negativo are ethics that illustrate that every time someone feels threatened or powerless, that person is likely to lash out in violence. Posthuman ethics cannot be realized if we do not acknowledge ourselves as the (active or passive) perpetrators of violence in the first place, as the general declaration of guilt in the text and the statement that it matters what we make of it suggests. Both short stories demonstrate that the violence employed against an Other inevitably leads to the destruction of the one who perpetrated the violence. This is at the core of posthuman ethics: Acts of violence destroy the "humanity" of the perpetrators and also reposition the life of the perpetrator as precarious. This way, a different logic is revealed through the short stories, one of ethical "laws" and principles. As the narrator writes about the flock of sheep in "Das Manöver": "Die Tiere gehorch[]en anderen Gesetzen" ("The animals obey different laws", [9], p. 120). These "Gesetze", laws or principles, do no bow to the right of the stronger one or the presumed superiority of man, as the sheep's refusal to budge in "Die Tat" demonstrates. These "other laws" and the gaze of the animal challenge the laws of men and call their ethical implications into question. The laws in question are the ones based on the discourse and institution of speciesism. Posthuman ethics demonstrate how the violence against the Other leads inevitably to the destruction of the one who sought to "protect" himself from that otherness.

Schnurre's short stories reckon with a humanism that has lost its meaning after WWII-the atrocities committed during the Third Reich and the reduction of life (whether human or animal) to bare life are part of the historical heritage of the war. Furthermore, an accusation against those who simply went along with and supported these atrocities is clearly identifiable in Schnurre's texts, most poignantly in "Die Tat", as Adelhoefer (see [21]) has also pointed out. Since Schnurre mostly uses animal figures to present his argument, his stories beg the question of whether we are not all Mitläufer (uncritical followers) even today, not only with regard to our treatment of animals, but also all the other ways in which we continue to discriminate between lives that deserve respect and protection, and those that do not. Finally, they highlight how violence is used as a tool to deny Others individuality

11 While Schnurre focuses on male protagonists and does not concern himself with the question of female guilt or violence, his short stories imply that anyone who subscribes to a model of strong over weak and unconnected life can become guilty in an ethical sense. As he shows in "Die Tat", even powerless children are not beyond the temptation of violence, which suggests that the ethically unsound world of carno-phallogocentrism is not exclusively one of able, adult men-and thus has to be understood as a concept that does not necessarily run parallel to gender distinctions. 
and agency, and how models of subjectivity that rely on hierarchical power structures and implicit as well as explicit violence against Others are no longer valid. Schnurre's short stories can help to enact a kind of posthumanism that acknowledges and values the deep entanglement between human actions, animal lives, and the creaturely suffering of all living beings.

As the short stories show, posthuman ethics have to be born out of the recognition that our current ethical model, which excludes non-human Others, is not only harmful to the animal Other, but ultimately to the human as well, since it transports violent behavioral patterns. It is only through this realization that posthuman ethics can be created. As the key scenes of encounter between humans and non-human Others in the short stories lay out, this posthuman ethics cannot be built on yet another categorization of life forms and prescriptive ethical imperatives. Rather, it has to be negotiated in the moment of the one-on-one encounter that first acknowledges the common basis of being alive and the vulnerability of life in general. This will require an acknowledgement of human life as precarious as well as interconnected, similar to Butler's conception of ethics. The moment of encounter that is central according to the logic of Schnurre's short stories is not by chance an encounter between real (and not symbolic/allegorical) creatures: Only in the moment of the encounter of both bodies can life be experienced as precarious. ${ }^{12}$ This aspect of embodiment is also something that Butler highlights: "some ethical claims emerge from bodily life and perhaps all ethical claims presuppose a bodily life, understood as injurable, one that is not restrictively human" ([8], p. 147). Butler does not explain how this awareness of embodied existence and an acknowledgement of interdependency can concretely be achieved, and while she mentions the role of violence, it seems limited to the species context. ${ }^{13}$ In line with Schnurre's short stories, the moment of (posthuman) ethical awakening has to be the moment of a real, physical, "embodied" encounter. Posthuman ethical awakening means seeing the face (in the Levinasian sense) of an Other, and experiencing ourselves as precarious life. It is also an awareness that we are connected to the precarious life of the Other across from us. Rather than an abstract acknowledgement of precariousness and embodiment, Schnurre's short stories point to an experienced precariousness in the moment of the face-to-face encounter. Only the real ${ }^{14}$, pregnant cat and the ram in their embodied subjectivity can call upon the awareness of the human across from them and can mirror in their suffering of violence the end of humanity-and the moment in which a posthuman conception of encountering is called for. From the encounter with the real (diegetic) cat in "Die Tat", a kind of haunting spirit is born, and the gazes of the cats in the story will oscillate between those of imagined, eerie presence (the allegorical cat), and the real cats the protagonists encounter. The allegorical cat, the haunting spirit, is the reminder of the encounter of violence and loss of humanity and becomes the symbol of posthuman ethics. It is this abstract cat, the memory of the precarious life experienced in violence, that causes Zabel to later act ethically and save the second diegetic cat from the river Dnjeper. From the real encounter and the experience of violence on both sides, posthuman ethics are thus born from the experience of life as vulnerable, and an understanding that we are always already the Other in our precarious state, and violence can only destroy both self and Other.

Conflicts of Interest: The author declares no conflict of interest.

\section{References}

1. Giorgio Agamben. The Open: Man and Animal. Stanford: Stanford University Press, 2004.

2. Peter Singer. Animal Liberation, 2nd ed. New York: New York Review, 1990.

12 Many animals are indeed physically superior to us in an one-on-one encounter.

13 In her article, she makes repeated reference to life beyond the species boundary of the human, yet only cites it. In her book on precarious life, she mostly sticks with human constellations, which limits its application to a posthuman ethics.

14 Real in the meaning of diegetic - not a symbolic or allegorical animal. 
3. Jacques Derrida. "Eating Well', or the Calculation of the Subject: An Interview with Jacques Derrida." In Who Comes after the Subject? Edited by Peter Connor, Eduardo Dadava and Jean-Luc Nancy. New York: Routledge, 1991, pp. 96-119.

4. Cary Wolfe. Animal Rites. American Culture, the Discourse of Species, and Posthuman Theory. Chicago: University of Chicago Press, 2003.

5. Cary Wolfe. What is Posthumanism? Minneapolis: University of Minnesota Press, 2010.

6. Cary Wolfe. “Human, all too human: 'Animal studies' and the humanities." PMLA 124 (2009): 564-75. [CrossRef]

7. Roberto Esposito. Bíos. Biopolitics and Philosophy. Minneapolis: University of Minnesota Press, 2008.

8. Judith Butler. "Precarious Life, Vulnerability, and the Ethics of Cohabitation." The Journal of Speculative Philosophy 26 (2012): 134-51.

9. Gerlinde Heindl. "Die grausame Logik des Karnophallogozentrismus in Carmen Boullosas Son vacas, somos puercos." In Über die Grenzen des Natürlichen Lebens. Inszenierungsformen des Mensch-Tier-Maschine-Verhältnisses in der Iberoromania. Edited by Christopher F. Laferl and Claudia Leitner. Wien: Lit, 2009, pp. 109-22.

10. Carrie Rohman. “'Dämonische Reife': Identität, Verzehr und der Spezies-Diskurs in The Plumed Serpent." In Über die Grenzen des Natürlichen Lebens. Inszenierungsformen des Mensch-Tier-Maschine-Verhältnisses in der Iberoromania. Edited by Christopher F. Laferl and Claudia Leitner. Wien: Lit, 2009, pp. 97-108.

11. Wolfdietrich Schnurre. “Die Tat.” In Eine Rechnung, Die Nicht Aufgeht. München: List, 1960, pp. 72-85.

12. Wolfdietrich Schnurre. "Das Manöver." In Eine Rechnung, Die Nicht Aufgeht. München: List, 1960, pp. 117-25.

13. Manfred Durzak. Die deutsche Kurzgeschichte der Gegenwart. Autorenporträts, Werkstattgespräche, Interpretationen. Stuttgart: Reclam, 1980.

14. Boria Sax. Animas in the Third Reich. Pets, Scapegoats, and the Holocaust. Mount Vernon: Decalogue, 2009.

15. Charles Patterson. Eternal Treblinka. Our Treatment of Animals and the Holocaust. New York: Lantern Books, 2002.

16. Gilles Deleuze, and Felix Guattari. Tausend Plateaus. Kapitalismus und Schizophrenie. Berlin: Merve, 1992.

17. Giorgio Agamben. Homo Sacer. Sovereign Power and Bare Life. Stanford: Stanford University Press, 1998.

18. Wolfdietrich Schnurre. "Kritik und Waffe. Zur Problematik der Kurzgeschichte." In Wolfdietrich Schnurre. Erzählungen 1945-1965. München: List, 1977, pp. 388-96.

19. Daniela Schwardt. Fabelnd denken. Zur Schreib- und Wirkungsabsicht von Wolfdietrich Schnurre. Oldenburg: Igel Verlag, 1999.

20. Emmanuel Levinas. Humanism of the Other. Urbana: University of Illinois Press, 2003.

21. Günter Butzer, and Joachim Jacob, eds. Metzler Lexikon literarischer Symbole, 2nd ed. Stuttgart and Weimar: Metzler, 2012.

22. Henk ten Have. Vulnerability. Challenging Bioethics. New York: Routledge, 2016.

23. David L. Clark. "What remains to be seen: Animal, atrocity, witness." In "Animots": Postanimality in French Thought. Edited by David L. Clark, Matthew Senior and Carla Frecerro. New Haven: Yale University Press, 2015, pp. 143-717.

24. Jacques Derrida. The Animal That Therefore I Am. New York: Fordham University Press, 2008.

25. David L. Clark. “On being the last Kantian in Nazi Germany.” In Animal Acts. Configuring the Human in Western History. Edited by Matthew Senior and Jennifer Ham. New York: Routledge, 1997, pp. 165-98.

26. Emmanuel Levinas. "The name of a dog or natural rights." In Difficult Freedom: Essays on Judaism. London: The Athlone Press, 1990, pp. 151-53.

27. Jacques Derrida. The Beast and the Sovereign. Chicago and London: University of Chicago Press, 2009 , vol. 1.

28. Judith Still. Derrida and Hospitality. Theory and Practice. Edinburgh: Edinburgh University Press, 2010.

29. Mathias Adelhoefer. Wolfdietrich Schnurre: Ein deutscher Nachkriegsautor. Pfaffenweiler: Centaurus, 1990.

(C) 2016 by the author; licensee MDPI, Basel, Switzerland. This article is an open access article distributed under the terms and conditions of the Creative Commons Attribution (CC-BY) license (http://creativecommons.org/licenses/by/4.0/). 